\title{
Archiwum pisarza, topografia jego utworów i ich potencjał dydaktyczny. O dwóch opowiadaniach Włodzimierza Odojewskiego z Wielkopolską, Poznaniem i archiwum w tle
}

\author{
The writer's archive, topography of his works and his didactic \\ potential. About two short stores by Włodzimierz Odojewski \\ with Greater Poland and Poznań in the background
}

\author{
|Dagmara Nowakowska \\ Uniwersytet im. Adama Mickiewicza w Poznaniu
}

\begin{abstract}
The author of the article focuses on the biography and prose of Włodzimierz Odojewski - one of the most important contemporary Polish writers. Since 2008, his literary archive has been collected at the Faculty of Polish and Classical Philology at the Adam Mickiewicz University in Poznań. The aim of the work is to indicate how archival collection can be used in the didactic work at various stages of education. The text is, as well, a kind of proposal for teachers how to familiarize students with Odojewski's work. First part of the article shows the documents (manuscripts, typescripts, correspondence related to stages of writer's life cycle) as a source of knowledge about the author's life and history of his literary output, and also describes some of the archivist's tasks. The second outlines the places in Greater Poland significant for the writer - Poznań and Kłecko, described in his short stories. These stories are examples of individual memory saved in literary texts.

Key words: literary archive, regional studies, biography, history of literature, geopoetics

Streszczenie: Autorka artykułu skupia się na biografii i prozie Włodzimierza Odojewskiego - jednego z najważniejszych współczesnych polskich pisarzy. Od 2008 jego spuścizna literacka jest gromadzona na Wydziale Filologii Polskiej i Klasycznej Uniwersytetu im. Adama Mickiewicza w Poznaniu. Celem pracy jest wskazanie, jak zbiór archiwalny może być wykorzystany w dydaktyce na różnych etapach kształcenia. Tekst stanowi również swego rodzaju propozycję dla nauczycieli, jak zaznajomić uczniów i studentów z twórczością Odojewskiego. Część pierwsza pokazuje dokumenty archiwalne (rękopisy, maszynopisy, korespondencję powstałe w różnych etapach życia pisarza) jako źródło wiedzy o biografii autora i dziejach jego twórczości, jak również przybliża pracę archiwisty. Druga część przedstawia znaczące dla Odojewskiego miejsca w Wielkopolsce, opisane w jego opowiadaniach, które stanowią indywidualne zapisy pamięci zachowane w tekstach literackich.
\end{abstract}

Słowa kluczowe: archiwum literackie, regionalistyka, biografia, historia literatury, geopoetyka

Od 2008 roku na Wydziale Filologii Polskiej i Klasycznej Uniwersytetu im. Adama Mickiewicza w Poznaniu gromadzona jest spuścizna literacka 
Włodzimierza Odojewskiego - jednego z najważniejszych twórców polskiej literatury powojennej. Na jego ogromny dorobek artystyczny składają się powieści, opowiadania, dramaty, słuchowiska radiowe, prace krytycznoliterackie. Przez wiele lat pracował w redakcji Polskiego Radia w Warszawie, a później w Radiu Wolna Europa w Monachium. Uhonorowany został wieloma prestiżowymi nagrodami, m. in. Fundacji Kościelskich, Związku Pisarzy Polskich na Obczyźnie, paryskiej „Kultury” i londyńskich „Wiadomości”, Szwedzkiego Komitetu Katyńskiego, nowojorskiej Fundacji im. A. Jurzykowskiego, polskiego PEN-Clubu, Ministerstwa Kultury i Sztuki, miesięcznika „Odra”, nagrodą im. Władysława Reymonta.

Otwarcie Archiwum Odojewskiego w 2017 roku ujawniło potencjał badawczy tej pokaźnej kolekcji, składającej się m.in. z maszynopisów, rękopisów, prywatnej biblioteki i korespondencji pisarza. To ważne, nie tylko dla literaturoznawstwa, wydarzenie przypadło na okres szczególnego zainteresowania archiwami zwanego „zwrotem archiwalnym” (Ulicka, 2017). Poprawa koniunktury archiwów i postulat powrotu do tradycyjnej filologii spowodowały, że zarówno praktyka, jak i teoria archiwum przestały być domeną historyków, a zaczęły pojawiać się w różnych obszarach nauki. Badacze na nowo pochylają się nad rękopisami i brulionowymi wersjami dzieł, wykorzystując narzędzia wypracowane przez genetykę tekstów i kulturową teorię literatury, by odkrywać zupełnie nowe aspekty i konteksty procesu tekstotwórczego i materii archiwalnej. Archiwum jest tu metaforą odwołującą się do aktu porządkowania, systematyzacji i mechanizmów pracy pamięci, ale przede wszystkim realnym repozytorium materialnych świadectw historii.

Nieznane dotąd dokumenty, skrywane w domowym archiwum i stanowiące pisarski warsztat pracy autora Zasypie wszystko, zawieje..., zostały ujawnione i stały się przedmiotem namysłu badaczy reprezentujących rozmaite dziedziny nauki - nie tylko historyków literatury, ale także językoznawców, filmoznawców czy regionalistów. Pisarz przekazał poznańskiej uczelni zbiór unikatowy, stanowiący cenne źródło dla dalszych prac badawczych literaturoznawców, historyków emigracji i historyków kultury. To także ważny składnik tradycji regionu wielkopolskiego i samego Poznania (miejsce urodzenia, dzieciństwa i młodości pisarza). Tu otwiera się szerokie pole działania dla regionalistów, lokalnych animatorów kultury, nauczycieli.

Odojewski bez wątpienia jest jedną z najwybitniejszych postaci kultury wywodzących się z Poznania i związanych z Wielkopolską, nie tylko przez pochodzenie i związki rodzinne, ale również przez twórczość - region został zaznaczony w jego pisarstwie. Wątki wielkopolskie wplecione są w narrację „cyklu podolskiego" (Piotr Czerestwienski pochodzi z Wielkopolski, jego powojenne losy opisane zostały w opowiadaniu Spisywane z pamięci), ale przede wszystkim poświęcono im opowiadania. Tym bardziej dziwi nieobecność Odojewskiego jako pisarza pochodzącego z Poznania w świadomości czytelników, a zwłaszcza mieszkańców miasta. Wydarzenia organizowane 
wokół Archiwum - spotkania, wystawy, konferencje naukowe - przyciągają coraz bardziej liczną grupę zainteresowanych Odojewskim, ale kluczowe w tej kwestii jest zaznajomienie z jego twórczością młodych czytelników na etapie edukacji szkolnej i akademickiej.

Inspiracją do napisania tego tekstu była wyprawa do wielkopolskich miejsc związanych z Włodzimierzem Odojewskim zorganizowana w maju 2018 roku. Grupa badaczy zajmujących się twórczością autora Wyspy ocalenia postanowiła przemierzyć szlak jednej z ostatnich wizyt Odojewskiego w stronach rodzinnych, która miała miejsce w roku 2007. Pisarz odwiedził wtedy m.in. Kłecko i Gniezno. Okazało się wówczas, że wczytując się we współczesną topografię Kłecka i analizując opowiadania Ikonka Siergija i Ostatni Żyd w miasteczku można rozpoznać opisane w nich miejsca. Tak narodził się pomysł opracowania kilkuetapowego projektu dydaktycznego, możliwego do wykorzystania na różnych poziomach edukacji, np. na etapie liceum lub kształcenia akademickiego (tu przedstawiam jego szkicową, wstępną wersję). Poznańskie archiwum stanowi punkt wyjścia w tym projekcie, a materia archiwalna prowokuje do wyjścia z klasy czy sali wykładowej, dlatego ma on mieć charakter zajęć terenowych możliwych do zrealizowania na lekcjach języka polskiego lub regionalistyki.

\section{Archiwum jako repozytorium wiedzy o autorze i procesie tekstotwórczym}

W Archiwum Odojewskiego znajduje się oryginalne biurko pisarza, na którym ustawiono zgromadzone po nim pamiątki. Wśród nich są maszyna do pisania, będąca narzędziem pracy Odojewskiego w redakcji Radia Wolna Europa (dziś rzadko spotykany relikt pisarskiej rzeczywistości), a także jego prywatny komputer. Te dwa urządzenia służące do utrwalania myśli w postaci zapisu słów i łączenia ich $\mathrm{w}$ teksty stanowią materialne znaki czasu. Pióro zastąpione przez maszynę do pisania, a potem zamienione na komputer są świadectwem wpływu zdobyczy techniki na formy tekstu kultury, ale także dokumentem tego, jak ten sam tekst rozrasta się i jak zmienia się jego treść. Rękopisy zostały zastąpione przez maszynopisy, a potem pliki zapisywane na dysku. Teksty najpierw rozrastały się w stosy brulionów, by zniknąć skumulowane w ikonach pulpitu komputera. To wszystko uzmysławia rozciągłość czasową procesu tekstotwórczego i pozwala zrekonstruować pisarski zwyczaj Odojewskiego. Autor Zmierzchu świata pozostawił setki maszynopisów, w znacznej części niedatowanych. Większość napisanych przez niego utworów, oprócz wersji wydanych, to również od kilku do kilkudziesięciu wersji zachowanych w formie maszynopisów, powstających w różnych fazach jego twórczości, często uzupełnianych fragmentami rękopiśmiennymi. Bezustannie udoskonalał swoje dzieła: zapisywał całe marginesy, doklejał dodawane passusy do tekstu głównego, notował między wierszami i na odwrocie kart. Odojewski korzystał nie tylko 
z maszynopisów, ale także z kserokopii tekstów wydanych. Poprawki nanosił również w opublikowanych książkach. Stanowią one zupełnie odrębne warianty utworów. Taka metoda twórcza sprawia, że właściwie żadnego z tekstów autora Oksany nie możemy uznać za wersję ostateczną. Wszystkie składają się na zasób, określony przez krytyków genetycznych jako „przed-tekst”. Śledzenie zmian w tekstach niewydanych, porównywanie z wszystkimi edycjami umożliwia odtworzenie i analizę poszczególnych etapów procesu twórczego i pisarskiej aktywności Odojewskiego. Badanie procesu tekstotwórczego wymaga opracowania narracyjnej reprezentacji dossier (Antoniuk 2017, 43). Analiza dostępnych wersji brulionowych pozwala ocenić poszczególne etapy wytwarzania tekstu i śledzić jego materialne przemiany. Krytyk genetyczny podejmuje próbę określenia chronologicznego porządku powstawania tekstów i zależności między nimi, zmiany tożsamości gatunkowej, np. kiedy opowiadanie rozrasta się w powieść lub wyłączony fragment powieści staje się samodzielnym tekstem.

Archiwum to także miejsce pracy biografa. Materia archiwalna zawiera nie tylko dokumentacje pracy pisarskiej, ale osobiste papiery czy rodzinne pamiątki, które rzucają nowe światło na artystyczne wybory i biograficzne losy pisarza. Wyjątkowy status ma zatem korespondencja pisarza, stanowiąca zapis uczestnictwa Odojewskiego w życiu literackim krajowym, emigracyjnym i międzynarodowym. Liczący setki listów zbiór pozwala osadzić proces twórczy w szerokim kontekście biograficznym. Nazwiska korespondentów tworzą sieć powiązań i relacji, które dają się rozszyfrować po zagłębieniu się w treści listów i są bezcennym źródłem wiedzy o życiu autora, powojennej historii Polski i dziejów polskiej emigracji intelektualnej. Ale warto też zwrócić uwagę na pułapki zastawiane przez archiwum. Jedną z nich jest bezkrytyczne podejście do źródeł archiwalnych i „naiwne zaufanie dokumentom" tylko dlatego, że są archiwaliami (Ulicka 2017). Warunkiem koniecznym jest zatem krytyczna analiza zawartości archiwum, prześwietlająca pozostawiony materiał jako tekst kultury powstały w określonych okolicznościach (kontekst historyczny, kulturowy) i celach przez napisany konkretnego autora $\mathrm{z}$ uwzględnieniem specyfiki jego języka, indywidualnego idiolektu. Analiza archiwaliów i próba chronologicznego uporządkowania wiadomości o życiu autora jest szczególnie cenna, gdyż materia archiwalna wskazuje na inne szlaki twórcze niż te usankcjonowane przez historię literatury (Przybyszewska 2018, 94). Zachowany materiał ujawnia wiele związków Odojewskiego z Poznaniem i uzasadnia lokalizację Archiwum w miejscu urodzenia pisarza. Tu spędził on pierwsze dziewięć lat swojego życia i ważny etap aktywności twórczej (lata 50.), tu studiował i nawiązał znajomości z poznańskim środowiskiem intelektualnym, m. in. z Józefem Ratajczakiem czy Marianem Grześczakiem. Świadczą o tym zachowane listy, których lektura pomaga zrekonstruować fragmenty artystycznej biografii autora Oksany. Na podstawie zgromadzonych archiwaliów udało się dotrzeć do wielu nieznanych dotąd faktów z życia pisarza. 
Jednym z nich jest owiana tajemnicą sprawa nagłego wyjazdu Odojewskiego z Poznania do Szczecina w 1947 roku. W wywiadach pisarz wspominał:

Zacząłem chodzić do trzeciej klasy gimnazjum. Dzisiaj z lekkim humorem wspominam, że wtedy właśnie, mając lat szesnaście, uciekłem od mamy. Uciekłem do ojca, który był w Szczecinie. (...) Wydawało mi się, że uwalniam się od miłosnego tyraństwa mamy. (...) Do tego dodajmy, że wychowywałem się w domu pełnym ciotek, byłem jedynym mężczyzną. Kochano mnie, rozpieszczano, ale ja uciekłem przed zbyt słodką miłością (Zaworska 2002, 256).

Po wojnie ojciec pisarza znalazł zatrudnienie w szczecińskiej filharmonii, wkrótce dołączył do niego syn, który w Szczecinie właśnie zadebiutował w świecie literackim. Powód przeprowadzki był istotny i, oprócz chęci uwolnienia się spod matczynej opieki, miał jeszcze jeden istotny powód. Zaraz po wojnie Odojewski rozpoczął naukę w technikum handlowym w Gnieźnie, którą przerwał po pierwszym roku. Wrócił do Poznania i podjął naukę w męskim Liceum Św. Marii Magdaleny, rozwiązanym przez władze komunistyczne w 1950 roku po zabójstwie Jana Stachowiaka, aktywisty Związku Walki Młodych. Ta sprawa zaważyła na dalszych losach pisarza.

W styczniu 1947 roku w ruinach kościoła Bernardynów w Poznaniu dwaj członkowie Konspiracyjnego Związku Młodzieży Wielkopolskiej i zrazem uczniowie Liceum Św. Marii Magdaleny w Poznaniu zamordowali kolegę ze szkolnej ławy. Do szczegółów bulwersujących ówczesną opinię publiczną wydarzeń dotarł Adam Białobłocki, analizując dokumentację Wojskowego Sądu Rejonowego w Poznaniu oraz lokalną prasę, co opisał w książce Tragiczny proces 1947 - Gimnazjum i Liceum Św. Marii Magdaleny w Poznaniu. Dzieje prowokacji i likwidacji uczelni i 15-tej Drużyny Harcerskiej im. Romualda Traugutta. W szkole istniała tajna komórka niepodległościowa kierowana przez Marka Harkiewicza, dobrze znana służbom bezpieczeństwa. Konflikt i animozje w organizacji doprowadziły do wykluczenia jednego z uczniów - wspomnianego Jana Stachowiaka, zwerbowanego wkrótce przez ZWM i ORMO i wykorzystywanego do inwigilacji byłych kolegów. Zdrajcę ukarano wyrokiem śmierci. Domniemanych zabójców Stachowiaka - Zbigniewa Kosmowskiego i Bogdana Dybizbańskiego - ujęto i po nagłośnionym przez propagandę szybkim procesie skazano na śmierć, a ciał straconych nigdy nie wydano rodzinom (Białobłocki 2003). Wtedy też zintensyfikowały się działania służb wobec 15. Poznańskiej Drużyny Harcerskiej im. Romualda Traugutta. Rodzice Odojewskiego, pamiętający jeszcze perturbacje związane $\mathrm{z}$ osadzeniem syna $\mathrm{w}$ areszcie gestapo, świadomi, że jego związki z harcerstwem i AK mogą wyjść na jaw podczas prześwietlania uczniów przez służby, zdecydowali, że będzie on kontynuował naukę w Szczecinie. Tym uchronili oni syna przed prześladowaniami. Być może zmiana nazwiska Jasiński na Odojewski wiąże się właśnie z tą sprawą. Ta wciąż pozostaje otwarta. W tym kontekście archiwum możemy potraktować jako swego rodzaju laboratorium, w którym archiwista wciela się w różne role - historyka literatury, krytyka genetycznego, 
biografa, interpretatora. Co istotne, Archiwum nie ogranicza, ale wywołuje badacza poza jego zamkniętą przestrzeń. Odsyła do konkretnych miejsc, m.in. na mapie Poznania i Wielkopolski.

\section{Topografie pamięci}

\section{Kłecko}

W badaniach nad prozą Odojewskiego i jej związkami z regionem wielkopolskim punktem odniesienia dla zwrotu archiwalnego jest zwrot przestrzenny, a ściślej biorąc - zwrot topograficzny, będący jego „lokalnym” wariantem. Obecnie obserwujemy renesans problematyki spacjalnej we współczesnej humanistyce. Świadectwem tego są badania interakcji między kulturą a przestrzenią, rosnąca popularność turystyki kulturowej, a także tendencja tworzenia atlasów literatury, poświęconych związkom literatury z miejscem - rzeczywiście istniejącym lub wykreowanym przez autora. W przypadku interesujących mnie opowiadań Odojewskiego, relacja miejsca i literatury czy też - ściślej rzecz ujmując - miejsca i autora, dotyczy jego bezpośrednich związków rodzinnych lub miejsc zaznaczonych przez niego obecnością. Problem ten można opisać dwojako. Po pierwsze, posługując się terminem „refrakcja” zapożyczonym z optyki. W takim przypadku literatura traktowana jest jako „pryzmat, który przekształca autentyczne loci w miejsca literackie" (Rybicka 2014, 36), czego przykładem może być Kłecko w opowiadaniu Ostatni Żyd $w$ miasteczku lub Poznań z opowiadania Spisywane z pamięci. Po drugie, odwołując się do zagadnień nurtu regionalizmu literackiego - geobiografii, procesów wytwarzania topografii regionu i relacji między przestrzenią geograficzną a twórczością literacką (Rybicka 2014, 340). Wydaje się, że w odniesieniu do dwóch wymienionych opowiadań szczególnie przydatną kategorią okazuje się geobiografia, opisująca związki autora z miejscami uobecnionymi w twórczości oraz wpływ interakcji miejsca i historii na jego życie. Przykładem może być okres kłeckowski biografii Odojewskiego. W Kłecku mieszkali dziadkowie pisarza ze strony matki. Rodzina Jasińskich przeniosła się tam na czas okupacji. W prozie Odojewskiego Kłecko pojawia się jeszcze w kilku opowiadaniach - Frau, komm!, Ikonka Siergija, Pogrzebany. Interesujące mnie opowiadanie Ostatni Żyd w miasteczku wydaje się szczególnie ważne. W wywiadzie udzielonym Hannie Zaworskiej pisarz wspominał, że w Kłecku po raz pierwszy doświadczył okrucieństwa wojny:

Z makabrą wojenną zetknąłem się już w końcu 1939 roku, w Wielkopolsce, w tym miasteczku, w którym właśnie mieszkaliśmy. Miasteczko, położone między jeziorami, po prostu zatrzymało na półtora dnia w roku 1939 armię niemiecką. Ono się skutecznie broniło. Jak Niemcy weszli, w dwóch czy trzech ratach wystrzelali kilkuset ludzi. Polaków, Żydów, uciekinierów, okolicznych chłopów (Zaworska 2002, 255). 
Opowiadanie można potraktować jako zapis jednego z pierwszych obrazów wojny zapamiętanych przez autora Wyspy ocalenia. Przedstawiona została konkretna lokacja czasowa i przestrzenna wydarzeń: Kłecko w pierwszych miesiącach wojny, ale już po pogromach:

Był początek, a może połowa listopada, kiedy mama wyprawiła mnie i Maryjkę z Poznania do Kłecka, ówczesnego miejsca zamieszkania dziadków. Miałem wtedy dziewięć lat. Dokładniej to dziewięć i pięć miesięcy. Wysłała mnie razem z siostrą Maryjką pod czyjąś tam opieką na wieś, bo to tak się zwykle mówiło: na wieś, jedziemy na wieś, przebywaliśmy na wsi, wróciliśmy ze wsi, choć - konkretnie - wieś ta była miasteczkiem, i to wcale nie tak małym, liczyła bowiem kilkaset mieszkańców. (...)

Wtedy wciąż było jeszcze jesiennie ciepło. Światło słoneczne rozlewało się po niebie bez chmur aż po odległy o kilometry horyzont, zamglone nieco, ale mimo to jasne. Dziadkowie pędzili nas z domu na podwórze, do ogrodu, nad pobliskie jezioro, na łąki nad jeziorem i za jeziorem. Byle byśmy nie siedzieli wśród czterech ścian. I nie wysłuchiwali, o czym oni, dorośli, mówią. Mieliśmy się bawić. Tym bardziej, że już znaliśmy całą gromadę rówieśników z okolicznych domów, którzy do szkoły nie poszli, bo szkoły dla Polaków nie było. „Bawcie się, tylko nie oddalajcie się zbytnio, bo coś się może stać!”. Nie mówili wprawdzie, co stać się może, ale to już dowiedzieliśmy się bez trudu sami. Co stać się może, jeżeli nie będzie się uważało. A dowiedzieliśmy się od miejscowych, więc bardziej rozeznanych we wszystkim, pamiętających, co się w miasteczku działo niedawno jeszcze, bo widzieli na własne oczy (Odojewski 2007).

W opowiadaniu Odojewski nawiązał do problematyki Zagłady i uwiecznił społeczność kłeckowskich Żydów. W Wielkopolsce ludności żydowskiej było niewiele, inaczej niż na Podolu, gdzie w dzieciństwie pisarz spędzał wakacje. Kresowe miasteczka zamieszkiwali żydowscy kupcy i rzemieślnicy, wtedy miał okazje zobaczyć chasydów w tradycyjnych strojach. Kłeckowska diaspora była nieliczna, ale przed wojną w miasteczku były synagoga i kirkut, sąsiadujący z cmentarzami ewangelickim i katolickim. Dziś nie ma po nich śladu. Magdalena Rabizo-Birek, kreśląc obraz Żydów w wykreowanym przez Odojewskiego kresowym imaginarium, podkreśla, że postaci Żydów pojawiają się jako drugoplanowe, „widziane są przez pryzmat wojny i to w szczególnym jej momencie" (Rabizo-Birek 2002, 49). Tę uwage można odnieść do opowiadania Ostatni Żyd w miasteczku. Dzieci stają się przypadkowymi świadkami ostatniej drogi milczącego przechodnia - tytułowego Żyda.

Ale ja przecież nie chcę tutaj snuć historii miasteczka, ani tego, co się zdarzyło w samym miasteczku i wokół niego w pierwszych dniach wojny, czego sam nie widziałem a znałem z cudzych relacji tylko, ale o tym późno-listopadowym już poranku, kiedy skrzyknęliśmy się całą paczką opodal rynku; pewnie z pięciu chłopaków nas było i dwie dziewczyny (pamięć mnie chyba nie zawodzi), i mieliśmy zamiar pójść na bagna Świętej Barbary za miasteczkiem, gdzie w pobliżu starego, pocholerycznego cmentarza na wzgórku, były tuż obok, na wpół w bagnach utopione, dobrze widoczne ślady przedwojennego jeszcze wykopaliska starosłowiańskiego, 
wtedy rozkopanego i przez wojnę zaniechanego. Chcieliśmy pochodzić tam w „te i we w te", rozejrzeć się i pogrzebać w ziemi (...).

Bo jak tylko tą główną ulicą prowadzącą od rynku zbliżyliśmy się do jej końca, gdzie ostatni dom po lewej stronie to była piekarnia i następnie jakieś z dwie albo trzy chałupki w jednym rzędzie, a dalej mleczarnia jeszcze i już koniec, już poza miasteczkowe łąki (ale do mleczarni nie dochodząc), to ujrzeliśmy, jak z bocznej, przed tą mleczarnią wąskiej uliczki od jeziora prowadzącej, wyszedł Żyd. W czarnym chałacie i białych, wyłaniających się z butów skarpetach, z czarną jarmułką na głowie. Nie młody, nie stary, w średnich latach jeszcze i wysokiej, pokaźnej postury.

Żyd z brodą, równo na wysokości pół piersi przyciętą. Patrzący gdzieś daleko przed siebie, nie na nas. Ale musiał nas widzieć, bo zanim się z nami zrównał, w odległości paru kroków, zbliżając się, zszedł z chodnika na bruk jezdni, ustępując nam z drogi; potem, idąc po tych „kocich łbach” jezdni minął nas, i dopiero, gdy podchodził do pustego o tej porze rynku, na powrót wkroczył na chodnik (Odojewski 2007).

Z dawnego Kłecka opisanego w opowiadaniu zachowały się domy przy ulicy Dworcowej (główna ulica prowadząca z Świętej Barbary do rynku) i odchodzące od niej boczne uliczki, prowadzące do jeziora. W miejscu piekarni i mleczarni jest dziś restauracja, a komisariat niemiecki zamieniono na prywatne mieszkania. Brukowana jezdnia została przykryta asfaltem. W przestrzeni dzisiejszego miasteczka nie ma śladów tamtego zdarzenia, ale możliwe jest zlokalizowanie miejsc wspomnianych $\mathrm{w}$ opowiadaniu. Historia kłeckowskiego Żyda jest pojedynczym świadectwem pamięci indywidualnej, utrwalonej za pośrednictwem medium, jakim jest tekst literacki. Odojewski dokonuje tu rekonstrukcji wydarzeń, które miały miejsce niemal siedemdziesiąt lat wcześniej. Żyd idzie na śmierć w milczeniu, niepotrzebne tu są żadne słowa, wszystko się już dokonało. Dzieci są bezsilnymi, biernymi świadkami Holokaustu, ale dokonuje się w nich przemiana, inicjacja w rzeczy ostateczne, zostają dotknięte przez śmierć:

Patrzyliśmy za nim, stojąc tam w tym samym miejscu, gdzie nas minął, jak zastygli, bez słowa, nie potrafiąc odezwać się do siebie tak długo, aż się gdzieś u przeciwległego wylotu rynku zupełnie oddalił, w uliczkę prowadzącą obok kościoła ewangelickiego się wtopił. A wtedy, jeszcze zanim któryś z nas powiedział jakieś słowo, jedna z dziewczyn zaczęła cicho płakać. Druga, starsza ją objęła, przytuliła i głaskała po plecach. Jeden z chłopaków nagle powiedział cicho: „On się gdzieś tutaj ukrywał. Ale nikt go nie wydał”. „Miał dość” dorzucił drugi, najstarszy z nas, najbardziej doświadczony. Jakoś tak twardo, ostro. A ten pierwszy chłopak powiedział na to: „On poszedł do niemieckiego komisariatu za rynkiem”, równie ostro jak tamten. Dziewczyny zaś dalej płakały. I każdy z nas już wiedział, że on, ten napotkany właśnie Żyd, tak uroczyście na czarno ubrany, szedł na śmierć. Bo tyle już o niej wiedzieliśmy. Więc to było tak, jak byśmy wszyscy razem o śmierć raptem się otarli (Odojewski 2007).

Przypadek tytułowego ostatniego kłeckowskiego Żyda przywoływany jest z pokładów pamięci i opowiedziany z perspektywy wielu lat. Pojawia się we wspomnieniach narratora nagle: „Nie wiem, dlaczego mi się to wszystko teraz właśnie przypomina (...) Ale może komuś z mieszkających 
tam dzisiaj opowiedziałbym tę historię". To nie jest pamięć, która ocala przedwojenny świat i mieszkańców wielkopolskiego miasteczka, ale brzemię historii i, jak zostało to ujęte w ostatnich słowach opowiadania, „straszliwe memento". Przestroga dla przyszłych pokoleń, która wskazuje na coś jeszcze - na niebezpieczeństwo zapomnienia, które niesie zagrożenie powtórzenia się tej historii.

\section{Poznań}

Opowiadanie Spisywane z pamięci (1963) z tomu Jedźmy, wracajmy to przykład kreślenia literackiej mapy poznańskiego śródmieścia, w którą zostały wpisane wydarzenia z Czerwca 1956 roku

Dom przy Alei, przed domem ogród, drzewa stojące bez ruchu w dusznym upale tego czwartku, bezchmurne niebo, pusta ulica i niedaleko karabinowa palba (...). W gęstym dwuszeregu rozłożystych kasztanów - aleja, w ich cieniu zielono pomalowane ławki ustawione symetrycznie (...) w ogrodach dwa rzędy domków jednorodzinnych willi, żółtych, białych albo żółto-białych (...) dalej na kamienistym nasypie z rzadka porosłym trawą, tu i ówdzie wypaloną i sczerniałą, kolejowy tor (...) parę czworoboków wyższych budynków, przeważnie secesyjnych kamienic czynszowych, między którymi wznosił się szpital imienia Raszei, opodal zabudowania otaczające gmach Urzędu Bezpieczeństwa, górujący nad resztą otoczenia, następnie garaże, oraz okrągły, kopulasty pawilon ujeżdżalni koni, wszystko to rozgrodzone ulicami i uliczkami przepełnionymi huczącym jak ul tłumem, ponad tym zaś bezchmurne niebo, podobnie nieruchome, jak znieruchomiały wydał mu się na krótko cały widok okolicy (Odojewski 2000, 328-330).

Kluczowe wydają się tu dwie sprawy - krajobraz miasta wyłaniający się z pamięci narratora, obserwatora i uczestnika czerwcowego buntu, który $\mathrm{w}$ więziennej celi odtwarza drogę prowadzącą z dzielnicy Sołacz do centrum miasta, gdzie znajdowało się epicentrum wydarzeń, ale także historia - imperatyw utrwalenia obrazów wyjątkowych w powojennych dziejach miasta. Historia została w wpisana w topografię miasta. Czas opowiadania dzieli się na to, co przed i po wypadkach czerwcowych.

[z]iemia kolebka i grób, miejsce, które zajmujemy pod niebem, przesycona przez pokolenia naszym potem, krwią i wspomnieniami, ta ziemia, gdzie być może nawet po śmierci jako duchy niewidzialne towarzyszyć będziemy naszym bliskim żywym tak długo, dopóki pamięć o nas nie wygaśnie (...) czy to może zapisuje się na ulicach miasta nowa karta historii tej ziemi (...) i sobie pomyślał, że coś się z nim dzisiaj stało, jakby przed laty był umarł i teraz znowu się narodził, i że człowieka, prawdziwego, pełnego człowieka wykuwa nie tyle niesprawiedliwość, ile ta chwila dopiero, kiedy goryczy jest już o kroplę za dużo (Odojewski 2000, 337-338).

Odojewski utrwala momenty, które były jego osobistym doświadczeniem, kształtowały go jako człowieka i twórcę. Zapis jest jednocześnie śladem wewnętrznej przemiany pisarza. Warto zwrócić uwagę na fakt, że rok 1956 stanowi ważną cezurę $\mathrm{w}$ pisarstwie Odojewskiego. Trudno oszacować dziś, w jakim stopniu miały na to wpływ poznańskie wydarzenia, ale 
wypada zaznaczyć, że jest to czas pożegnania z konwencją socrealistyczną i okres tworzenia literatury dla młodzieży - w roku następnym pisarz wyda dwie powieści Spisek Czarnych Orłów i Żeglarzy Króla Jegomości. W połowie roku 1956 rozpoczęła się jego współpraca z „Tygodnikiem Zachodnim” i Wydawnictwem Poznańskim, powołanymi na fali październikowej odwilży. W „Tygodniku Zachodnim” Odojewski pełnił funkcję zastępcy redaktora naczelnego, a pisane przez niego teksty miały charakter rewizjonistyczny. W tym czasie powstały również dwa tomy zbiorowe opowiadań Bez dogmatów oraz Codzienna ściana płaczu/Po tamtej stronie oceanu, ocenione przez cenzora jako zbyt antyradzieckie i wycofane z edycji (Przybyszewska 2018, 97-99). Znającym topografię Poznania i zaznajomionym z historią życia Odojewskiego nietrudno dostrzec miejsca wspólne jego biografii i doświadczeń bohatera-narratora. Można nawet pokusić się o wskazanie na wymiar autobiograficzny tego opowiadania. W czasie wydarzeń czerwcowych Odojewski mieszkał w Poznaniu, a passus o domu przy kasztanowej alei, przywodzi na myśl okolice willi Bystrzyckich, w której mieszkał wówczas z żoną Janiną. I jak bohater opowiadania oczekiwał narodzin dziecka.

Wydarzenia opisane w opowiadaniu skupiają się wokół dwóch miejsc w przestrzeni Poznania - gmachu Wojewódzkiego Urzędu Bezpieczeństwa przy ulicy Kochanowskiego, by potem przenieść się do szpitala mieszczącego się w dzielnicy Łazarz (obecnie ulica Jarochowskiego 18). Sceny rozgrywające się $\mathrm{w}$ centrum miasta to seria szybko następujących po sobie obrazów odtwarzanych pracą pamięci bohatera-narratora w konwencji sennych majaków, m.in. do dziś owiana tajemnicą śmierć Romka Strzałkowskiego:

[s]tał z rana z Barbarą $\mathrm{w}$ tłumie manifestujących przed uniwersytetem i jak ten, niby wezbrana fala, doniósł ich przed Urząd Bezpieczeństwa i że już wtedy ludzie mówili, że jakiś chłopiec pobiegł w stronę gmachu, powiewając biało-czerwoną chorągiewką, być może, aby zetknąć ją u wejścia i że nagle padł strzał i chłopiec dostał kulą, co mogło być prawdą, bo ten niewielki kawałek biało-czerwonego płótna, skrwawionego i oddartego od drzewca obnoszono i pokazywano (Odojewski 2000, 338).

Opisana przez Odojewskiego wędrówka przez Poznań pogrążony w gorączce czerwcowego buntu wpisuje się w koncepcję map mentalnych miast, wywodzącą się z psychologii poznawczej, będących zapisami indywidualnych wyobrażeń przestrzeni. Charakterystyczną ich cechą są wybiórczość, subiektywność i niepowtarzalność wyznaczające obszar krzyżowania się pamięci i przestrzeni (Saryusz-Wolska 2011, 152-153). Oba miejsca są ze sobą ściśle związane. Budynek szpitala opisanego w opowiadaniu miał w przeszłości inne przeznaczenie. Przed wojną mieścił się tu klasztor Karmelitek Bosych, a w czasie wojny szkoła muzyczna dla młodzieży niemieckiej. Po 1945 roku urządzono tam siedzibę Urzędu Bezpieczeństwa, najpierw wojewódzkiego, a po przeniesieniu go na ulicę Kochanowskiego, miejskiego. Od 1952 roku w gmachu mieścił się szpital ginekologiczno-położniczy. 
Zdarzenia, które mają miejsce w szpitalu dzieją się kilka miesięcy po wypadkach czerwcowych. Odojewski odkrywa podskórną tkankę miasta. Tajemnice przeszłości szpitala zostają ujawnione w rozmowie bohatera-narratora z położną. Przyszpitalny ogród jest cmentarzem, pod powierzchnią ziemi kryją się ciała pozbawionych imienia ofiar aparatu bezpieczeństwa, tych, którzy odważyli się przeciwstawić władzy ludowej. Gmach szpitala to palimpsest - farba na ścianach łuszczy się, wyzierają z niej brunatne plamy - ślady krwi zakatowanych tu żołnierzy Armii Krajowej i innych wrogów systemu. Ich groby porastają bujne, kwieciste klomby i trawniki:

Wszystko to groby, panie Piotrze. Widzi pan, jakie te klomby i trawniki wysokie? A tam pod murem? Gdzie te krzewy? Wszystko to groby. Zanim budynek oddano z powrotem klinice, było tu UB. Przez dwa lata po wojnie. Rozstrzeliwali i grzebali. Pan wie, gdzie tylko się ruszyć sama krzywda akowców i wszystkich tych, co mieli jakieś znaczenie, albo nie taili, że myślą inaczej niż oni. (...) Nikt nie wie po nazwisku kogo, nikt nie wie ilu. Może tylko ten ogrodnik, bo on tutaj był i przedtem. Coś mu się w głowie od tamtego czasu zepsuło. Czasem, jak się upije, to gada, że ludzie tu leżą warstwami (Odojewski 2000, 347-348).

Obraz ukrytej w zieleni nekropolii można odczytać dwojako: po pierwsze, jako historię, która niczym rośliny przebija się powoli przez grubą warstwę przygniatających ją kłamstw; po drugie, jako dobrze ukrytą, straszną prawdę o zbrodni. Ale to również metafora ogrodu pamięci, która przezwycięża kłamstwo i zbrodnię.

Przywołane tu przykłady wykorzystania materiałów archiwalnych w dydaktyce prowokują do dalszej eksploracji archiwum i otwierają szersze perspektywy dla nauczycieli. Kłeckowskie retrospekcje można uzupełnić o odczytanie opowiadań Ikonka Siergija i Frau, komm! Równie ważnym miejscem jak Poznań czy Kłecko w twórczej biografii Odojewskiego jest Gniezno, gdzie w czasie okupacji był on więziony przez gestapo za działalność harcerską. Miasto z czasów okupacji niemieckiej jest tłem wydarzeń opisanych w opowiadaniu Lekcja intymności. Ciekawy przypadek mogłaby stanowić analiza korespondencji Odojewskiego z pisarzami i ludźmi kultury z poznańskiego środowiska twórczego, będąca świadectwem życia literackiego w powojennym Poznaniu, którego autor Wyspy ocalenia był aktywnym uczestnikiem. Byłaby to okazja do zaznajomienia uczniów i studentów z ważnym aspektem dziejów miasta i osobami, które dziś często bywają zapomniane.

\section{Bibliografia:}

Antoniuk Mateusz, 2017, Jak czytać stronę brulionu. Krytyka genetyczna i materialność tekstu, „Wielogłos”, nr 1.

Białobłocki Adam, 2003, Tragiczny proces 1947. Gimnazjum i Liceum Św. Marii Magdaleny w Poznaniu - dzieje prowokacji i likwidacji uczelni i 15-tej Poznańskiej Drużyny Harcerskiej im. Romualda Traugutta, Poznań. 
Nowakowska Dagmara, 2014, Wielkopolska Włodzimierza Odojewskiego. Przyczynek do biografii, „Przegląd Wielkopolski”, nr 105.

Odojewski Włodzimierz, 2007, Ostatni Żyd w miasteczku, „Fraza”, nr 67, http://fraza.univ.rzeszow.pl/numer/nr67-podrozni 2.php [dostęp: 06.04.2019].

Odojewski Włodzimierz, 2000, Spisywane z pamięci, w: Jedźmy, wracajmy, Warszawa.

Przybyszewska Alicja, 2018, Poznańskie lata Odojewskiego. Przyczynek do kalendarium życia i twórczości (i edycji książek zaniechanych), w: Zabezpieczanie śladów. Wokół życia i twórczości Włodzimierza Odojewskiego, Przybyszewska A., Nowakowska D. (red.), Poznań.

Rabizo-Birek Magdalena, 2002, Między mitem a historia. Twórczość Włodzimierza Odojewskiego, Warszawa.

Rybicka Elżbieta, 2014, Geopoetyka. Przestrzeń i miejsce we współczesnych teoriach i praktykach literackich, Kraków.

Saryusz-Wolska Magdalena, 2011, Spotkania czasu z miejscem. Studia o pamięci i miastach, Warszawa.

Śladami zbrodni w Wielkopolsce w latach 1945-1956. Projekt naukowo-badawczy Instytutu Pamięci Narodowej: https://slady.ipn.gov.pl/sz/projekt-naukowobadawc/wojewodztwo wielkopols/poznan/13164,Poznan-dawna-siedziba-UBprzy-ul-Jarochowskiego-18.html [dostęp: 10.04.2019].

Ulicka Danuta, 2017, „Archiwum” i archiwum, „Teksty Drugie”, nr 4, https://journals.openedition.org/td/1440 [dostęp: 09.04.2019].

Ulicka Danuta, 2010, Zwrot archiwalny (jak ja go widzę), „Teksty Drugie”, nr 1-2.

Zaworska Hanna, 2002, Udręka i uroda życia. Rozmowa Włodzimierzem Odojewskim, w: Dobrze, $\dot{z} e \dot{z} y ł e m$. Rozmowy z pisarzami, Warszawa.

\section{O Autorce:}

Dagmara Nowakowska - dokumentalista, pracuje w Archiwum Włodzimierza Odojewskiego przy Wydziale Filologii Polskiej i Klasycznej Uniwersytetu im. Adama Mickiewicza w Poznaniu, gdzie od 2011 roku opracowuje spuściznę literacką pisarza. Autorka rozprawy doktorskiej Indie romantyków. $Z$ recepcji Indii $w$ epoce polskiego romantyzmu. Interesuje się życiem polskiej powojennej emigracji intelektualnej, historią europejskiej indologii, biografistyką i regionalistyką literacką. Współpracuje z Wielkopolskim Towarzystwem Kulturalnym. Publikowała w czasopismach naukowych (m. in. „Studia Norwidiana”, „Pamiętnik Literacki”) i w tomach zbiorowych. Jest współredaktorką książki Zabezpieczanie śladów. Wokół życia i twórczości Włodzimierza Odojewskiego. 